University of Nebraska - Lincoln

DigitalCommons@University of Nebraska - Lincoln

Mammalogy Papers: University of Nebraska

State Museum

Museum, University of Nebraska State

4-2011

\title{
Identification and Characterization of the Contact Zone between Short-Tailed Shrews (Blarina) in lowa and Missouri
}

Cody W. Thompson

Texas Tech University, cody.thompson@ttu.edu

R. S. Pfau

Tarleton State University, pfau@tarleton.edu

Jerry R. Choate

Sternberg Museum of Natural History, Fort Hays State University

Hugh H. Genoways

University of Nebraska - Lincoln, h.h.genoways@gmail.com

Elmer J. Finck

Fort Hays State University, efinck@fhsu.edu

Follow this and additional works at: https://digitalcommons.unl.edu/museummammalogy

Part of the Zoology Commons

Thompson, Cody W.; Pfau, R. S.; Choate, Jerry R.; Genoways, Hugh H.; and Finck, Elmer J., "Identification and Characterization of the Contact Zone between Short-Tailed Shrews (Blarina) in lowa and Missouri" (2011). Mammalogy Papers: University of Nebraska State Museum. 141.

https://digitalcommons.unl.edu/museummammalogy/141

This Article is brought to you for free and open access by the Museum, University of Nebraska State at DigitalCommons@University of Nebraska - Lincoln. It has been accepted for inclusion in Mammalogy Papers: University of Nebraska State Museum by an authorized administrator of DigitalCommons@University of Nebraska Lincoln. 


\title{
Identification and characterization of the contact zone between short-tailed shrews (Blarina) in lowa and Missouri
}

\author{
C.W. Thompson, R.S. Pfau, J.R. Choate, H.H. Genoways, and E.J. Finck
}

\begin{abstract}
Short-tailed shrews (genus Blarina Gray, 1838) are characterized by divergent karyotypes and are genetically distinct. Blarina species are similar morphologically but, in most cases, can be distinguished morphometrically. Blarina distributions tend to be parapatric along well-defined contact zones; however, it has been suggested that the northern short-tailed shrew (Blarina brevicauda (Say, 1823)) and Elliot's short-tailed shrew (Blarina hylophaga Elliot, 1899) occur sympatrically in Iowa and Missouri. To evaluate this possibility, 179 specimens were collected in southwestern Iowa and northwestern Missouri. Karyotypes and total length were used for field identification, and amplified fragment length polymorphism (AFLP) analysis was used to verify field identifications and to investigate the extent of hybridization. One hundred seventyeight of 179 specimens were identified to species. The one exception had a karyotype of B. brevicauda $(2 n=50, \mathrm{FN}=$ 48); however, AFLP analysis indicated that this individual was likely an $F_{1}$ hybrid. No backcrosses were detected, so it appears that introgression is minimal. The putative hybrid was trapped at a locality with $B$. brevicauda just north of a locality having only $B$. hylophaga. No locality contained both species. Therefore, these species are not broadly sympatric as has been suggested, but rather exhibit a distribution similar to the pattern of parapatry seen in most of the contact zones of Blarina.

Résumé : Les musaraignes à queue courte (du genre Blarina Gray, 1838) se caractérisent par des caryotypes divergents et sont génétiquement distinctes. Les espèces de Blarina sont semblables morphologiquement, mais dans la plupart des cas, la morphométrie permet de les distinguer. Les répartitions des Blarina ont tendance à être parapatriques le long de zones de contact bien définies; on croit néanmoins que la grande musaraigne à queue courte (Blarina brevicauda (Say, 1823)) et la musaraigne à queue courte d'Elliot (Blarina hylophaga Elliot, 1899) se retrouvent en sympatrie en Iowa et au Missouri. Afin de vérifier cette possibilité, nous avons récolté 179 spécimens dans le sud-ouest de l'Iowa et le nord-ouest du Missouri. Les caryotypes et la longueur totale nous ont servi pour les identifications de terrain et une analyse du polymorphisme des longueurs des segments amplifiés (AFLP) a permis de confirmer les identifications de terrain et de déterminer l'importance de l'hybridation. Des 179 spécimens, 178 ont été identifiés à l'espèce. La seule exception avait un caryotype de $B$. brevicauda $(2 n=50, \mathrm{FN}=48)$; cependant l'analyse de ALFP indique que cet individu est vraisemblablement un hybride de $\mathrm{F}_{1}$. Comme il n'y a aucune indication de rétrocroisement, l'introgression semble minimale. L'hybride putatif a été piégé dans une localité contenant $B$. brevicauda située juste au nord d'une localité où vit seulement $B$. hylophaga. Aucune localité ne contient les deux espèces. Les deux espèces ne possèdent donc pas une importante zone de sympatrie, comme on le croyait; ils ont plutôt une répartition parapatrique du type observé dans la plupart des zones de contact de Blarina.
\end{abstract}

[Traduit par la Rédaction]

\section{Introduction}

Distributions of mammalian species in North America experienced several contractions and expansions during the Pleistocene owing to cyclical glacial activity and climatic changes. The Pleistocene glaciations certainly had an impact on current distributions of mammals on the Great Plains (Hoffmann and Jones 1970; Klicka and Zink 1997; Sepkoski
1998; Hewitt 2000; Lister 2004; Barnosky 2005). Speciation in the genus Blarina Gray, 1838 has been associated with Pleistocene glacial events (Graham and Semken 1976; Schmidly and Brown 1979; Jones et al. 1984). An interpretation of the fossil record suggests that Blarina diverged during the Irvingtonian North American Land Mammal Age (0.51.8 million years ago), perhaps owing to glacial events, which led to the isolation of a northern population that be-

Received 30 June 2010. Accepted 7 January 2011. Published at www.nrcresearchpress.com/cjz on 12 April 2011.

C.W. Thompson* and E.J. Finck. Department of Biological Sciences, Fort Hays State University, 600 Park Street, Hays,

KS 67601-4099, USA.

R.S. Pfau. Department of Biological Sciences, Tarleton State University, Box T-0100, Stephenville, TX 76402, USA.

J.R. Choate. ${ }^{\dagger}$ Sternberg Museum of Natural History, Fort Hays State University, 3000 Sternberg Drive, Hays, KS 67601, USA.

H.H. Genoways. University of Nebraska State Museum, W436 Nebraska Hall, Lincoln, NE 68588-0514, USA.

Corresponding author: Cody W. Thompson (e-mail: cody.thompson@ttu.edu).

*Present address: Department of Biological Sciences, Texas Tech University, Box 43131, Lubbock, TX 79409-3131, USA.

${ }^{\dagger}$ Deceased. 
came the northern short-tailed shrew (Blarina brevicauda (Say, 1823)) and a southern population that later diverged during the Rancholabrean North American Land Mammal Age (10000 - 500000 years ago; Schmidly and Brown 1979; Jones et al. 1984). The southern speciation event resulted in Elliot's short-tailed shrew (Blarina hylophaga Elliot, 1899) in the west and the southern short-tailed shrew (Blarina carolinensis (Bachman, 1837)) in the east (Jones et al. 1984). A fourth species within the genus, Sherman's short-tailed shrew (Blarina shermani Hamilton, 1955), occurs in peninsular Florida but has not been linked to Pleistocene events (Benedict et al. 2006).

Three of these species have distinct karyotypes (B. brevicauda, B. carolinensis, and B. hylophaga; Genoways et al. 1977; George et al. 1981, 1982) and also can be distinguished easily with mitochondrial DNA (mtDNA) sequence data (Benedict 1999a, 1999b; Brant and Ortí 2002; Brant 2005; Reilly et al. 2005). Despite their genetic differences, Blarina species are similar morphologically but, in most instances, can be distinguished morphometrically (Blair 1939; Graham and Semken 1976; Jones et al. 1984; Kays and Wilson 2002; Reilly et al. 2005; Benedict et al. 2006). Wherever the distributions of these species approach, they exhibit parapatric relationships with little overlap at contact zones and little or no hybridization (Genoways and Choate 1972; Graham and Semken 1976; Bowles 1977; Ellis et al. 1978; Tate et al. 1980; Braun and Kennedy 1983; Jones et al. 1984; Benedict 1999b; Brant and Ortí 2002).

The best-studied contact zone between species of Blarina is between B. brevicauda and B. hylophaga (Fig. 1). Using morphometric characters, Jones (1964) first identified this contact zone in Nebraska. Genoways and Choate (1972) studied this contact zone further using morphometrics and discovered that it was narrow and parapatric with possible hybridization occurring. Using morphometrics and mtDNA sequence data, Benedict $(1999 a, 1999 b)$ re-examined the contact zone in Nebraska and ascertained that it was $2.9 \mathrm{~km}$ wide at its widest point, again indicating a parapatric distribution (see Fig. 1). Benedict $(1999 a, 1999 b)$ also concluded that occasional hybridization occurred but with little to no introgression.

Bowles (1975, 1977), also using morphometrics, confirmed the presence of the brevicauda-hylophaga contact zone in southwestern Iowa but found no indication of introgression. However, Moncrief et al. (1982) conducted a more detailed morphometric analysis of the contact zone in southern Iowa and northern Missouri and concluded that the two species occurred sympatrically in this area because of numerous intermediate-sized specimens (see Fig. 1). These findings are contrary to expectations given that the distribution is unquestionably parapatric in Nebraska and hybridization appears to be limited (Genoways and Choate 1972; Benedict $1999 a, 1999 b)$.

Given the conflicting results of these studies, a reassessment of the contact zone between these species in Iowa and Missouri is warranted. If these species are indeed sympatric in Iowa and Missouri but parapatric in Nebraska, there would be important implications regarding our understanding of contact zones with known hybridization (i.e., hybrid zones). There are few reported instances of broad sympatry occurring at contact zones between closely related species with low mobility (Moore 1977). Because of the numerous contact zones between Blarina species in the eastern US, these species provide an ideal opportunity to test current models of hybridization. Before such studies can be conducted, however, the relationships between the species must be clarified.

Our study addresses two questions: (1) are B. brevicauda and $B$. hylophaga parapatric or sympatric in Iowa and Missouri and (2) what is the extent of hybridization and introgression where the geographic ranges of the two species abut or overlap? We hypothesize that B. brevicauda and B. hylophaga are parapatric in Iowa and Missouri, as they are in Nebraska (Genoways and Choate 1972; Benedict 1999a, $1999 b$ ). We further hypothesize based on the findings of Moncrief et al. (1982) that the two species hybridize and introgress more in Iowa and Missouri than in Nebraska, which would explain the presence of the intermediate-sized specimens. To address these questions, we collected specimens along multiple transects (using field-generated karyotypes and total length to locate the contact zone) and then used amplified fragment length polymorphism (AFLP) analysis (Vos et al. 1995) to confirm field identifications, identify potential hybrids, and determine the extent of introgression. If our first hypothesis is correct, and the two species are actually parapatric, we will find a clear absence of sympatry among specimens positively identified using karyotypes and AFLPs. If the two species introgress more in Iowa-Missouri than $\mathrm{Ne}$ braska, the width of the hybrid zone as determined from AFLPs will exceed the $2.9 \mathrm{~km}$ described by Benedict (1999a, 1999b).

\section{Materials and methods}

\section{Study area}

The study area included counties north of Interstate 70 in Missouri and south of Interstate 80 in Iowa and focused on those counties west of Interstate 35 in southwestern Iowa and northwestern Missouri. The counties sampled in Iowa included Fremont, Mills, Montgomery, Page, Pottawattamie, and Taylor. In Missouri, the counties included Andrew, Atchison, Buchanan, Caldwell, Clinton, Daviess, Gentry, Harrison, Holt, Nodaway, Platte, Ray, and Worth (Fig. 2).

\section{Specimen collection}

Trapping began in May 2005 in the Missouri River Valley at the location of the contact zone found by Benedict (1999b). The specific location was just west of Interstate 29 along Plum Creek in Fremont County, Iowa. Transects were placed in a north-south direction to locate populations of $B$. brevicauda to the north and $B$. hylophaga to the south (see Fig. 2). Trapping sites of 50 Sherman live-traps (H.B. Sherman Traps, Inc., Tallahassee, Florida, USA) were placed in road ditches to take advantage of potentially high densities of the genus Blarina (Kaufman and Kaufman 1989; Kirsch 1997). Traps were baited with dry oats and spaced approximately $10 \mathrm{~m}$ apart with two traps per station. GPS coordinates at the beginning and the end of each transect were recorded using a Garmin eTrex Legend (Garmin International, Inc., Olathe, Kansas, USA) GPS unit. After locating $B$. brevicauda in the north and B. hylophaga in the south, trapping shifted eastward approximately $50 \mathrm{~km}$ at the same latitude to begin a new transect. Specimens were identified 
Fig. 1. Currently known geographic distributions of the northern short-tailed shrew (Blarina brevicauda) and Elliot's short-tailed shrew (Blarina hylophaga) in North America (George et al. 1982; Moncrief et al. 1982; Reilly et al. 2005). The distributions of both species, as well as the sympatric overlap of the distributions within Iowa and Missouri, are indicated in the map legend.

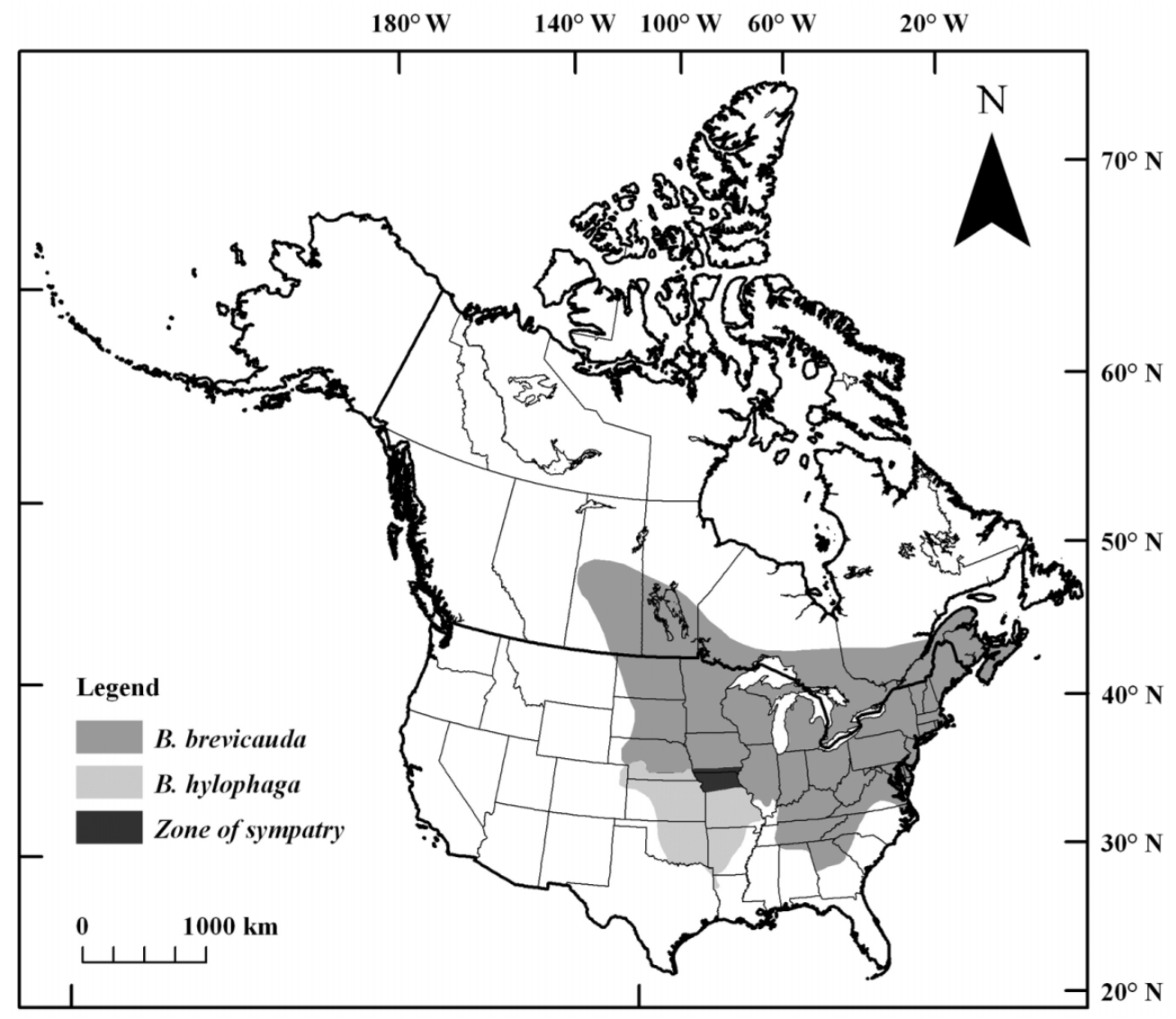

in the field by use of karyotypes and total length (described below). Trapping continued until November 2005 and traced the contact zone into Missouri to Interstate 35.

Collecting efforts resumed in May 2006. Blarina species were trapped as far as approximately $50 \mathrm{~km}$ north and south of the contact zone, with collecting efforts continuing beyond $50 \mathrm{~km}$ in the event that a contiguous line of the same species was not found. Additional specimens were collected within the probable contact zone to further refine its location and to analyze hybridization. The trapping protocol was the same as in 2005 .

Reference specimens were collected in the summer and fall of 2006. These specimens were collected in Harrison County, Iowa (B. brevicauda), and Ellis County, Kansas (B. hylophaga), outside the study area and away from areas of known contact between the two species. Animal care and use methods followed the guidelines of the American Society of Mammalogists (Gannon et al. 2007). Voucher specimens are housed in the Sternberg Museum of Natural History, Fort Hays State University (MHP).

\section{Field identification}

Karyotypes were essential for positive field identification of species (Genoways et al. 1977; George et al. 1982; Thompson and Hoffman 2009). Only those individuals that were alive within a half hour prior to karyotyping or were still warm to the touch were karyotyped. Karyotyping was performed as described by Baker et al. (2003) and are detailed by Thompson (2008).

Metaphase chromosome spreads were located with a Nikon Alphaphot YS microscope (Nikon Corp., Tokyo, Japan). Diploid and fundamental numbers of chromosomes were counted for each spread. Five to 10 spreads were photographed for each slide with a Nikon Coolpix 950 digital camera (Nikon Corp.), except when fewer than five spreads were found or in the event that chromosomal counts were not consistent (Sullivan et al. 1986; Baker et al. 1989), in which the most frequent count was used.

All standard external measurements (total length, tail length, hindfoot length, ear length, and mass; Martin et al. 2001) were recorded to assess their usefulness in identification in the field. Total length was used to provide tentative identification of specimens not karyotyped in the field. Specimens for which total length was $\geq 120 \mathrm{~mm}$ were identified as $B$. brevicauda. Specimens for which total length was $\leq 110 \mathrm{~mm}$ were identified as $B$. hylophaga. Specimens with total length between 110 and $120 \mathrm{~mm}$ were considered to be ambiguous or possible hybrids (Bowles 1975; Benedict 1999a; Schwartz and Schwartz 2001).

\section{AFLP analysis}

AFLPs were used to provide additional information for identification of species, to document hybridization, and to determine the extent of introgression. The AFLP protocol 
Fig. 2. Location of specimens collected in the study area in southwestern Iowa and northwestern Missouri. Solid circles indicate localities where northern short-tailed shrew (Blarina brevicauda) were collected. Solid triangles indicate localities where Elliot's short-tailed shrew (Blarina hylophaga) were collected. The asterisk indicates the location where the putative hybrid (MHP 37853) was trapped together with 10 specimens of B. brevicauda. Transects one to four are west to east in a north-south linear fashion. The inset shows the study area location (outlined) within Iowa (unshaded) and Missouri (shaded).

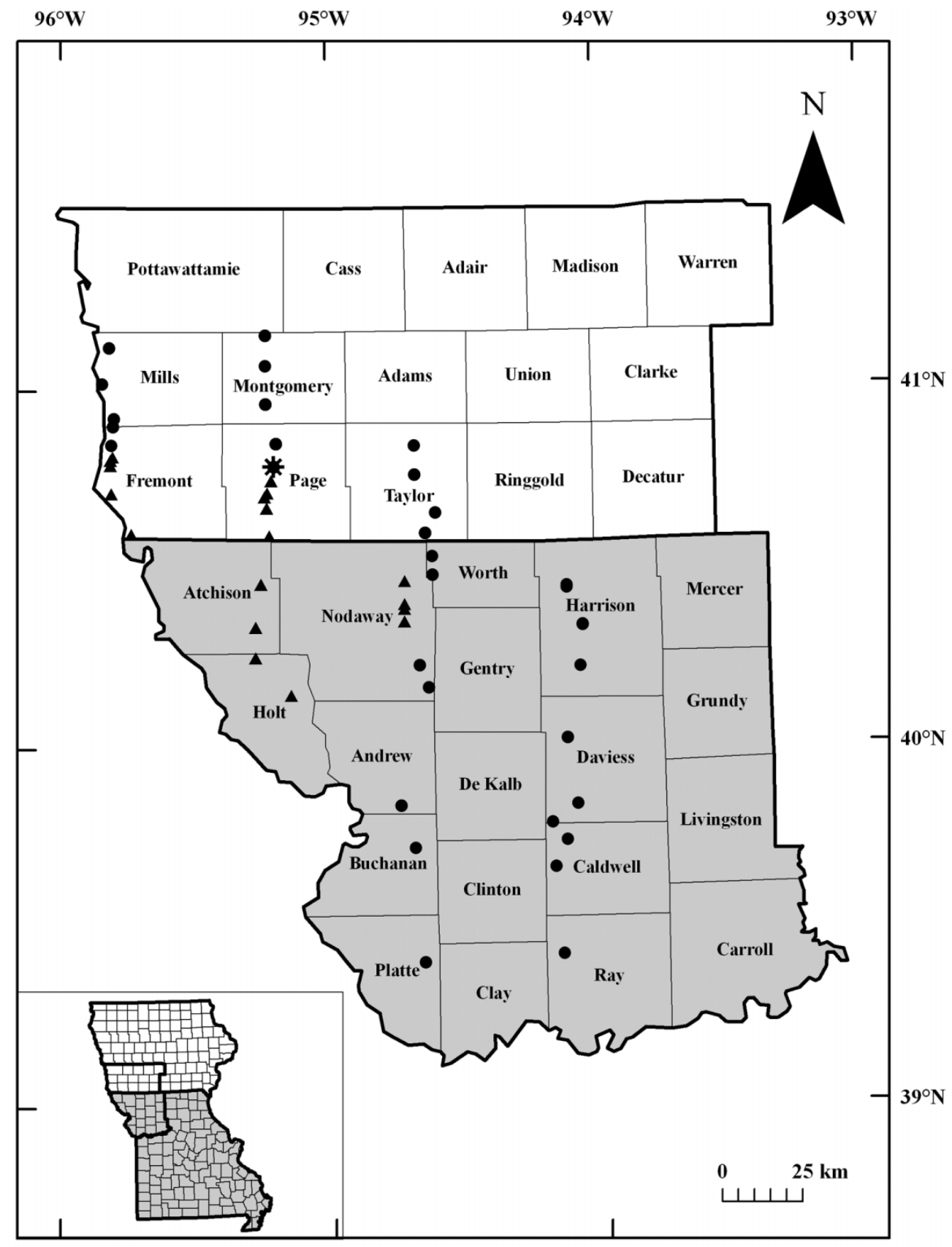

followed a technique (Phillips et al. 2007) modified from Vos et al. (1995). The following primer combinations were used: EcoRI-CAC and AseI-TAG, EcoRI-CAC and AseI-TCT, EcoRI-CAC and AseI-TGA, and EcoRI-CAT and AseI-TGA. Selective EcoRI primers were labeled fluorescently for detection by a Beckman-Coulter CEQ8000 Automated DNA Analysis System (Beckman-Coulter, Inc., Fullerton, California, USA). Beckman-Coulter software was used to size fragments based on an internal size standard. Only fragments that could be scored unambiguously as present or absent were in- cluded in the data set, which consisted of a table of ones indicating the presence of fragments of a certain size and zeros indicating their absence. Patterns of genetic divergence among individuals were determined by using principal coordinate analysis (PCoA) in GenAlEx version 6.1 (Peakall and Smouse 2006). STRUCTURE version 2.2 (Falush et al. 2007) was used to estimate each individual's admixture proportion $(q)$. The data file was formatted to take advantage of the ability of this version of STRUCTURE to account appropriately for the nature of dominant markers. Length of the 
burn-in period and number of iterations was set at 10000 and 50000 , respectively. The number of populations $(K)$ was set to two, representing the two species, but prior information regarding identification of species was not considered. Five independent runs were performed and the admixture proportions were averaged. NewHybrids version 1.1 beta (Anderson and Thompson 2002) was used to infer hybrid-class membership by calculating the posterior probability of an individual falling into one of six hybrid classes (pure B. hylophaga, B. hylophaga backcross, $\mathrm{F}_{1}, \mathrm{~F}_{2}, B$. brevicauda backcross, or pure $B$. brevicauda). Number of sweeps for burn-in and after burn-in was set to 10000 and 50000 , respectively. Information regarding identification of species was not considered a priori. Defaults were selected for all other settings. Likelihood values from five independent runs were averaged.

\section{Relationship in study area}

Trapping locations were placed into ArcMap (ESRI (Environmental Systems Research Institute, Inc.), Redlands, California, USA) to assess the spatial relationship between the distributions of the two species of Blarina. The definition of parapatry followed that of Mallet (2005: 230), where "2 groups of populations or species are parapatric if they abut at their range boundaries". This definition allows for gene flow between the groups but only at the limit of each species' geographic range, which can lead to a narrow band of hybridization or hybrid zone (Mallet 2005). Thereby, the distributional relationship was determined to be parapatric if the ranges of the species abutted but did not overlap (Futuyma and Mayer 1980; Key 1981; Moulton et al. 1983; Bull 1991; Mallet 2005). The distributional relationship was determined to be sympatric if the ranges significantly overlapped.

\section{Results}

\section{Specimen collection}

In total, 203 specimens were collected. Twenty-four specimens were collected as reference samples from four sites outside the study area: $10 \mathrm{~B}$. brevicauda were collected in Harrison County, Iowa, and 14 B. hylophaga were collected in Ellis County, Kansas. One hundred seventy-nine specimens were collected from 68 trapping locations along the four transects within the focal study area. Of those 179 specimens, 116 were collected in Iowa and 63 were collected in Missouri (see Appendix A). No individuals were collected in Pottawattamie County, Iowa, or Clinton and Gentry counties, Missouri.

\section{Field identification}

Eleven of the reference specimens were field karyotyped. Six specimens of $B$. brevicauda had a diploid number $(2 n)$ of 50 and one had 49 (all had a fundamental number (FN) of 48). Four specimens of B. hylophaga had a $2 n$ of 52 (all had an FN of 60). Fifty-four of the 100 specimens examined karyotypically within the study area were identified as $B$. brevicauda and 46 as $B$. hylophaga. Diploid numbers for $B$. brevicauda within the study area were 50,49, and 48 at a ratio of 27:19:7, respectively. Forty-four of these specimens had an FN of 48; the remaining nine specimens were not discernable. Diploid number for $B$. hylophaga within the study area was 52 , and FN were 62,61 , or 60 at a ratio of $6: 1: 23$, respectively.
Based on total length, 9 of the 24 reference specimens fell within the range expected of $B$. brevicauda and 14 within that expected of $B$. hylophaga. One specimen from within the range of B. hylophaga was intermediate. Also, 76 of the 179 specimens within the study area were designated as $B$. brevicauda and 67 as B. hylophaga (36 were intermediate).

\section{AFLP analysis}

AFLP data were obtained for all 203 specimens. Ninetytwo AFLP fragments were scored, with 59 (64.13\%) being polymorphic. The first two axes of the PCoA explained $89.75 \%$ of the variation in the AFLP data, with axis one differentiating the two species (Fig. 3). All reference specimens were placed into one of two distinct clusters as expected, allowing for unambiguous genetic identification. All individuals from the study area except one (MHP 37853, from transect two) fell within one of the two clusters. STRUCTURE analysis gave mean admixture proportions $(q)$ ranging from $96.2 \%$ to $99.9 \%$ for all individuals except MHP 37853 , which had a mean admixture proportion of $67.2 \%$. NewHybrids analysis identified one individual (MHP 37853) with a high mean likelihood of being an $\mathrm{F}_{1}$ hybrid (83.7\%); all other individuals had pure mean likelihood values ranging from $99.8 \%$ to $100 \%$.

\section{Identification using combined data}

Using karyotypes and (or) AFLP data, all 24 specimens from the reference localities were assigned unambiguously to the correct species. Twenty-three of these specimens were assigned correctly based on total length. The single morphological intermediate was genetically verified as $B$. brevicauda. The $10 \mathrm{~B}$. brevicauda averaged a total length of $122.8 \pm$ $2.7 \mathrm{~mm}$ (mean $\pm \mathrm{SD})(118-128 \mathrm{~mm})$, tail length of $27.2 \pm$ $1.5 \mathrm{~mm}(26-31 \mathrm{~mm})$, hindfoot length of $14.0 \pm 0.5 \mathrm{~mm}$ (13-15 mm), ear length of $0.0 \pm 0.0 \mathrm{~mm}$ (no range), and mass of $19.5 \pm 1.2 \mathrm{~g}(17-21.5 \mathrm{~g})$. The 14 B. hylophaga averaged a total length of $105.7 \pm 3.3 \mathrm{~mm}(100-110 \mathrm{~mm})$, tail length of $24.4 \pm 1.5 \mathrm{~mm}(12-28 \mathrm{~mm})$, hindfoot length of $11.9 \pm 0.5 \mathrm{~mm}(11-13 \mathrm{~mm})$, ear length of $0.0 \pm 0.0 \mathrm{~mm}$ (no range), and mass of $12.1 \pm 1.2 \mathrm{~g}(10.5-15.0 \mathrm{~g})$.

The 179 specimens from within the study area were identified unambiguously to species using karyotypes and (or) AFLP data. The 139 specimens assigned to species based on total length (excluding intermediates) were all assigned correctly. The individual identified as an $F_{1}$ hybrid (MHP 37853) using AFLP data was intermediate in size and had a $B$. brevicauda karyotype $(2 n=50 ; \mathrm{FN}=48)$. Blarina brevicauda averaged a total length of $124.5 \pm 7.5 \mathrm{~mm}$ (104$142 \mathrm{~mm})$, tail length of $28.0 \pm 2.7 \mathrm{~mm}(21-33 \mathrm{~mm})$, hindfoot length of $14.1 \pm 1.2 \mathrm{~mm}(8-19 \mathrm{~mm})$, ear length of $0.0 \pm 0.0 \mathrm{~mm}$ (no range), and mass of $18.9 \pm 3.5 \mathrm{~g}(9.0$ $29.5 \mathrm{~g})$. Blarina hylophaga averaged a total length of $106.3 \pm 5.0 \mathrm{~mm}(95-118 \mathrm{~mm})$, tail length of $22.0 \pm 4.7 \mathrm{~mm}$ (8-29 mm), hindfoot length of $12.2 \pm 0.7 \mathrm{~mm}(11-14 \mathrm{~mm})$, ear length of $0.0 \pm 0.0 \mathrm{~mm}$ (no range), and mass of $13.2 \pm$ $2.2 \mathrm{~g}(8.5-18.5 \mathrm{~g})$. The $\mathrm{F}_{1}$ hybrid (MHP 37853) was a female and had a total length, tail length, hindfoot length, ear length, and mass of $119 \mathrm{~mm}, 28 \mathrm{~mm}, 14 \mathrm{~mm}, 0 \mathrm{~mm}$, and $15.5 \mathrm{~g}$, respectively. 
Fig. 3. Plot of first two principal coordinates of the PCoA based on AFLP data of all specimens analyzed. Proportion of variation explained by each axis is indicated in parentheses. Specimens identified as the northern short-tailed shrew (Blarina brevicauda) are clustered on the left. Specimens identified as Elliot's short-tailed shrew (Blarina hylophaga) are clustered on the right. The putative hybrid (MHP 37853) is located intermediate to these two clusters.

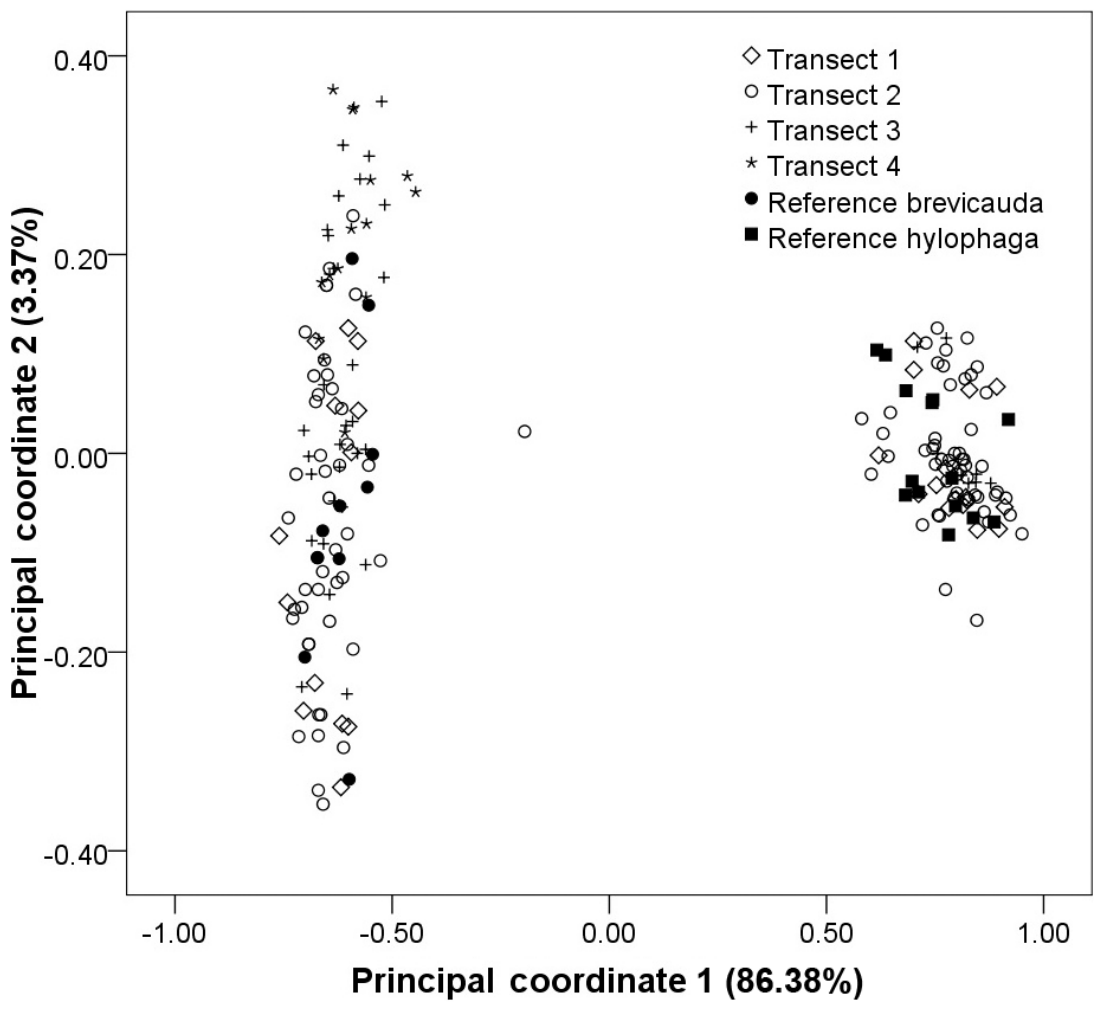

\section{Relationship in study area}

The contact zone is not broadly sympatric, but rather it appears to be parapatric (Fig. 2). This contact zone is apparent in transects one and two in Fremont and Page counties, Iowa, respectively. The third transect shows $B$. brevicauda occurring both north and south of locations with B. hylophaga in Nodaway County, Missouri. All individuals to the south of Nodaway County were identified as B. brevicauda; therefore, transect three crossed the contact zone in two places, which indicated an eastward extension of the distribution of B. hylophaga. Additionally, transect four only yielded $B$. brevicauda. Therefore, the distribution of $B$. hylophaga within the study area appeared to be at its easternmost extent in either eastern Nodaway County or western Gentry and (or) Worth counties (Fig. 2).

The hybrid specimen (MHP 37853) was obtained together with 10 B. brevicauda at a locality of transect two in Page County, Iowa. Adjacent localities to the north and south had only specimens of $B$. brevicauda and $B$. hylophaga, respectively. The nearest pure parental localities within this transect were $\sim 12.20 \mathrm{~km}$ apart. The nearest pure parental localities of transect one were separated by $\sim 3.71 \mathrm{~km}$. Distances between pure parental localities in transect three were $\sim 8.89$ and $\sim 14.33 \mathrm{~km}$ in the north and south, respectively (Fig. 2).

\section{Discussion}

\section{Characterization of the contact zone}

The distributions of $B$. brevicauda and B. hylophaga in the study are not broadly sympatric (Fig. 2) as suggested by
Moncrief et al. (1982). Rather, our results support the hypothesis of parapatry. In fact, the location of the contact zone in our study (Fig. 2) closely matches the parapatric distributions documented by Bowles $(1975,1977)$, which suggests that the contact zone has moved minimally in the past 30 years. Benedict $(1999 a, 1999 b)$ reported similar results with little movement of the contact zone in Nebraska since Genoways and Choate's (1972) study. The sympatric relationship observed by Moncrief et al. (1982) might have been the result of the inclusion of specimens from northeastern Kansas in the study specimens for B. hylophaga. It now is known that some of the specimens examined are from a presumed isolated population of B. brevicauda within this region of Kansas (Benedict 1999b). Given our finding of $B$. brevicauda in far western Missouri, it is possible that this population might not be isolated as once thought but rather might exist as an extension of $B$. brevicauda from Missouri into Kansas.

Benedict (1999b) noted that physical barriers separated the distributions between these two species in Nebraska. In this study, we found no obvious barrier along transects two and three. However, transect one is bisected by Plum Creek in Fremont County, Iowa, which separates the ranges of $B$. brevicauda and $B$. hylophaga. The strength of Plum Creek as a barrier seems low, given annual freezes during the winter months in this area and year-around activity of Blarina species (George et al. 1986; Genoways and Choate 1998). Roads also have been shown to be a barrier to the dispersal of Blarina species (Kirsch 1997; Benedict 1999b). Because of the large distances $(3.71-14.33 \mathrm{~km})$ separating the closest local- 
ities of B. brevicauda and B. hylophaga, we were unable to verify if roads act as barriers within our study area.

Given the absence of obvious barriers, interspecific interactions might influence the geographic relationship between these two species at their contact zones. These interactions hypothetically are balanced by climatic factors (Mayr 1963; Smith 1965; Genoways and Choate 1972; Graham and Semken 1976; Tate et al. 1980; Bull 1991; Frey 1992; Shaw et al. 1993; Benedict 1999a, 1999b; Hewitt 2001; Holt and Keitt 2005). One of the climatic factors that has been suggested to have an impact on the distribution of Blarina is temperature (Neal and Lustick 1973; McNab 1979; Genoud 1988), which would account for distributional shifts during the Pleistocene and Holocene with the advancing and retreating continental glacier. The larger-bodied B. brevicauda would be better adapted to colder climate and would have advanced southward as the glacier advanced. The alternative movement would have occurred with small-bodied B. hylophaga shifting northward during hypsithermal periods. The current distribution is the result of competing thermal needs of the species and the current temperature regiment enforced by the karyotypic differences of the species. This hypothesis seems plausible because ecotonal changes, which are maintained by the climate, appear to be a strong limiting factor in species distributions at contact zones (Smith 1965; Moulton et al. 1983; Bull 1991; Frey 1992; Harrison 1993; Searle 1993; Shaw et al. 1993; Hewitt 2000, 2001). However, we know of no environmental barriers associated with the contact zone of Blarina in our study area, as was reported in $\mathrm{Ne}$ braska (Benedict 1999b). In such instances, interspecific interactions, such as competition, parasite transmission, and reproductive interference (Benedict 1999b), might be sufficient and necessary to maintain the observed parapatric relationship in light of no discernible transition in the environment (Smith 1965; Endler 1977; Bull 1991; Turelli et al. 2001).

\section{Extent of hybridization and introgression}

Only 1 individual was identified as a hybrid $\left(\mathrm{F}_{1}\right)$ of the 29 individuals $(\sim 3.45 \%)$ from the locality at which it was captured and the two adjacent localities combined. Benedict (1999a) reported a higher proportion of hybrids in Nebraska than is reported herein contrary to our original hypothesis. Given that Benedict $(1999 a, 1999 b)$ collected many more individuals from the immediate vicinity of the contact zone, it is not surprising that he observed a greater proportion of hybrids. Additionally, Benedict's (1999a) technique of using morphology to identify hybrids would misclassify small B. brevicauda or large B. hylophaga as hybrids. Because we unambiguously identified specimens with karyotypes and AFLPs, we were able to assess the reliability of using morphology to identify hybrids. The potential for misclassification owing to the presence of small B. brevicauda and (or) large $B$. hylophaga near the contact zone is evident when looking at the extent of overlap in the ranges of external measurements seen among our genetically identified specimens. We observed a much greater range of measurements (thus greater overlap) at the study site relative to the reference sites. If we had relied only on the measurements from the reference site specimens to identify study site specimens, we would have a misidentification rate of $4.47 \%$ (8 of 179 specimens would be assigned to the incorrect species) based on total length (our most discriminating measurement based on reference site specimens). One of these eight specimens is the one identified as a hybrid based on AFLP analysis, which was within the size range of B. brevicauda. An additional $13.97 \%$ (25 of 179 ) were intermediate in size and might be presumed to be hybrids in the absence of karyotype or AFLP data.

We did not document introgression of nuclear DNA across the contact zone beyond the distance of our nearest transect sites. This lack of introgression might be due to differences in the number of Robertsonian polymorphisms that occurs within B. brevicauda and B. hylophaga (Meylan 1967; Lee and Zimmerman 1969; Genoways et al. 1977; George et al. 1982; Oshida et al. 2003), which likely reduces fitness (Searle 1993). Several hybrid zone studies have documented limited introgression between species with chromosomal rearrangements (Bradley et al. 1991; Basset et al. 2007; Genoways et al. 2008). Hybrid zones in which hybrids have reduced fitness can reduce or impede introgression between species (Baker et al. 1989; Searle 1993; Baker and Bradley 2006), which maintains the integrity of parental gene pools despite interbreeding (Bigelow 1965; Baker et al. 1989). Problems during the pairing and segregation phases of meiosis caused by increased chromosomal heterozygosity can reduce hybrid fitness (Baker and Bickham 1986). This explanation seems highly plausible given the number of Robertsonian polymorphisms that occurs within $B$. brevicauda and B. hylophaga (Meylan 1967; Lee and Zimmerman 1969; Genoways et al. 1977; George et al. 1982; Oshida et al. 2003; Thompson and Hoffman 2009). Thus, the chromosomal rearrangements between $B$. brevicauda and B. hylophaga might be a strong isolating mechanism (Shaw et al. 1993; Benedict et al. 2006). Our observed lack of introgression supports the hypothesis that $B$. brevicauda and B. hylophaga represent distinct species under the genetic species concept of Baker and Bradley (2006). Given that, in Nebraska, hybridization seems to occur most extensively within a zone of no more than $2 \mathrm{~km}$ in width (Genoways and Choate 1972; Benedict $1999 a, b$ ), we expect that a similar narrow hybrid zone will be defined in our study area if sampling is done on a finer scale.

\section{Distribution and conservation implications}

Special consideration needs to be given to the more precisely defined distributional limits of B. brevicauda and B. hylophaga in the study area. Our results revealed that $B$. hylophaga is located only in the northwestern and southwestern extremes of Missouri and Iowa, respectively. It also appears that $B$. brevicauda could extend from Missouri into Kansas and be connected to the presumed isolated population of B. brevicauda (George et al. 1982; Moncrief et al. 1982; Benedict 1999b). This change in our understanding of the distributions of these species has potential conservation implications.

Blarina hylophaga has been identified by the Iowa Wildlife Action Plan as being a species of greatest conservation need (Zohrer et al. 2006) and is a target species for the Multiple Species Inventory and Monitoring Program by the Iowa Department of Natural Resources (Kinkead 2006). We have shown that the distribution of B. hylophaga in Iowa is re- 
stricted to the southwestern counties of Fremont and Page. Bowles (1975) also found this species in adjacent Taylor County. Despite the limited distribution within the state, high densities have been reported previously in this area (Bowles 1975) and populations seemed to be in good condition during our fieldwork. Thus, B. hylophaga does not appear to be under significant conservation risk.

\section{Acknowledgments}

Portions of this research were supported by the Central Plains Society of Mammalogists and the Kansas Academy of Sciences. Additional funding came from the Fort Hays State University Department of Biological Sciences, Fort Hays State University Graduate School, and Tarleton State University Research Committee. Thanks also go to R.A. Benedict and M.J. Hamilton for advice in trapping and karyotyping, respectively. Additional thanks go to A.L. Sandquist, Iowa Department of Natural Resources, and Squaw Creek National Wildlife Refuge for providing housing. R.D. Bradley, R.B. Channell, E.T. Gillock, J.D. Hanson, R.N. Platt, and R.J. Zakrzewski reviewed an earlier draft of the manuscript.

\section{References}

Anderson, E.C., and Thompson, E.A. 2002. A model-based method for identifying species hybrids using multilocus genetic data. Genetics, 160(3): 1217-1229. PMID:11901135.

Baker, R.J., and Bickham, J.W. 1986. Speciation by monobrachial centric fusions. Proc. Natl. Acad. Sci. U.S.A. 83(21): 8245-8248. doi:10.1073/pnas.83.21.8245. PMID:16593777.

Baker, R.J., and Bradley, R.D. 2006. Speciation in mammals and the genetic species concept. J. Mammal. 87(4): 643-662. doi:10.1644/ 06-MAMM-F-038R2.1. PMID:19890476.

Baker, R.J., Davis, S.K., Bradley, R.D., Hamilton, M.J., and Van Den Bussche, R.A. 1989. Ribosomal-DNA, mitochondrial-DNA, chromosomal, and allozymic studies on a contact zone in the pocket gopher, Geomys. Evolution, 43(1): 63-75. doi:10.2307/ 2409164.

Baker, R.J., Hamilton, M., and Parish, D.A. 2003. Preparations of mammalian karyotypes under field conditions. Occas. Pap. Mus. Texas Tech Univ. 228: 1-8.

Barnosky, A.D. 2005. Effects of Quaternary climatic change on speciation in mammals. J. Mamm. Evol. 12(1-2): 247-264. doi:10.1007/s10914-005-4858-8.

Basset, P., Yannic, G., Brünner, H., and Hausser, J. 2007. Using a Bayesian method to assign individuals to karyotypic taxa in shrew hybrid zones. Cytogenet. Genome Res. 116(4): 282-288. doi:10. 1159/000100412. PMID:17431326.

Benedict, R.A. 1999a. Morphological and mitochondrial DNA variation in a hybrid zone between short-tailed shrews (Blarina) in Nebraska. J. Mammal. 80(1): 112-134. doi:10.2307/1383213.

Benedict, R.A. $1999 \mathrm{~b}$. Characteristics of a hybrid zone between two species of short-tailed shrews (Blarina). J. Mammal. 80(1): 135141. doi: $10.2307 / 1383214$.

Benedict, R.A., Genoways, H.H., and Choate, J.R. 2006. Taxonomy of short-tailed shrews (genus Blarina) in Florida. Occas. Pap. Mus. Texas Tech Univ. 251: 1-19.

Bigelow, R.S. 1965. Hybrid zones and reproductive isolation. Evolution, 19(4): 449-458. doi:10.2307/2406242.

Blair, W.F. 1939. Faunal relationships and geographic distribution of mammals in Oklahoma. Am. Midl. Nat. 22(1): 85-133. doi:10. 2307/2420398.

Bowles, J.B. 1975. Distribution and biogeography of mammals in
Iowa. Spec. Publ. Mus. Texas Tech Univ. Texas Tech Press, 9: $1-184$.

Bowles, J.B. 1977. Update of mammals of Fremont County. Iowa Bird Life, 47: 138-140.

Bradley, R.D., Davis, S.K., Lockwood, S.F., Bickham, J.W., and Baker, R.J. 1991. Hybrid breakdown and cellular-DNA content in a contact zone between two species of pocket gophers (Geomys). J. Mammal. 72(4): 697-705. doi:10.2307/1381830.

Brant, S.V. 2005. A review of the phylogeographic histories of shorttailed shrews (Insectivora: Soricidae) and their parasitic nematodes (Secernentea: Trichostrongylidae). In Advances in the biology of shrews. 2nd ed. Edited by J.F. Merritt, S. Churchfield, R. Hutterer, and B.I. Sheftel. Spec. Publ. Int. Soc. Shrew Biol. pp. 317-330.

Brant, S.V., and Ortí, G. 2002. Molecular phylogeny of short-tailed shrews, Blarina (Insectivora: Soricidae). Mol. Phylogenet. Evol. 22(2): 163-173. doi:10.1006/mpev.2001.1057. PMID:11820838.

Braun, J.K., and Kennedy, M.L. 1983. Systematics of the genus Blarina in Tennessee and adjacent areas. J. Mammal. 64(3): 414 425. doi: $10.2307 / 1380354$.

Bull, C.M. 1991. Ecology of parapatric distributions. Annu. Rev. Ecol. Syst. 22(1): 19-36. doi:10.1146/annurev.es.22.110191. 000315.

Ellis, L.S., Diersing, V.E., and Hoffmeister, D.F. 1978. Taxonomic status of short-tailed shrews (Blarina) in Illinois. J. Mammal. 59(2): 305-311. doi:10.2307/1379914.

Endler, J.A. 1977. Geographic variation, speciation, and clines. Princeton University Press, Princeton, N.J.

Falush, D., Stephens, M., and Pritchard, J.K. 2007. Inference of population structure using multilocus genotype data: dominant markers and null alleles. Mol. Ecol. Notes, 7(4): 574-578. doi:10. 1111/j.1471-8286.2007.01758.x. PMID:18784791.

Frey, J.K. 1992. Response of a mammalian faunal element to climatic changes. J. Mammal. 73(1): 43-50. doi:10.2307/1381864.

Futuyma, D.J., and Mayer, G.C. 1980. Non-allopatric speciation in animals. Syst. Zool. 29(3): 254-271. doi:10.2307/2412661.

Gannon, W.L., and Sikes, R.S. and Animal Care and Use Committee of the American Society of Mammalogists. 2007. Guidelines of the American Society of Mammalogists for the use of wild mammals in research. J. Mammal. 88(3): 809-823. doi:10.1644/ 06-MAMM-F-185R1.1.

Genoud, M. 1988. Energetic strategies of shrews: Ecological constraints and evolutionary implications. Mammal Rev. 18(4): 173-193. doi:10.1111/j.1365-2907.1988.tb00083.x.

Genoways, H.H., and Choate, J.R. 1972. A multivariate analysis of systematic relationships among populations of the short-tailed shrew (genus Blarina) in Nebraska. Syst. Zool. 21(1): 106-116. doi:10.2307/2412263.

Genoways, H.H., and Choate, J.R. 1998. Natural history of the southern short-tailed shrew, Blarina carolinensis. Occas. Pap. Mus. Southwest. Biol. 8: 1-43.

Genoways, H.H., Patton, J.C., III, and Choate, J.R. 1977. Karyotypes of shrews of the genera Cryptotis and Blarina (Mammalia: Soricidae). Experientia (Basel), 33(10): 1294-1295. doi:10.1007/ BF01920141.

Genoways, H.H., Hamilton, M.J., Bell, D.M., Chambers, R.R., and Bradley, R.D. 2008. Hybrid zones, genetic isolation, and systematics of pocket gophers (genus Geomys) in Nebraska. J. Mammal. 89(4): 826-836. doi:10.1644/07-MAMM-A-408.1.

George, S.B., Choate, J.R., and Genoways, H.H. 1981. Distribution and taxonomic status of Blarina hylophaga Elliot (Insectivora: Soricidae). Ann. Carnegie Mus. 50: 493-513.

George, S.B., Genoways, H.H., Choate, J.R., and Baker, R.J. 1982. Karyotypic relationships within the short-tailed shrews, genus Blarina. J. Mammal. 63(4): 639-645. doi:10.2307/1380269. 
George, S.B., Choate, J.R., and Genoways, H.H. 1986. Blarina brevicauda. Mamm. Species No. 261. pp. 1-9.

Graham, R.W., and Semken, H.A. 1976. Paleoecological significance of the short-tailed shrew (Blarina), with a systematic discussion of Blarina ozarkensis. J. Mammal. 57(3): 433-449. doi:10.2307/ 1379294.

Harrison, R.G. 1993. Hybrids and hybrid zones: historical perspective. In Hybrid zones and the evolutionary process. Edited by R.G. Harrison. Oxford University Press, Ithaca, N.Y. pp. 3-12.

Hewitt, G. 2000. The genetic legacy of the Quaternary ice ages. Nature (London), 405(6789): 907-913. doi:10.1038/35016000. PMID:10879524.

Hewitt, G.M. 2001. Speciation, hybrid zones, and phylogeography or seeing genes in space and time. Mol. Ecol. 10(3): 537-549. doi:10.1046/j.1365-294x.2001.01202.x. PMID:11298967.

Hoffmann, R.S., and Jones, J.K., Jr. 1970. Influence of late-glacial and post-glacial events on the distribution of recent mammals on the northern Great Plains. In Pleistocene and recent environments of the central Great Plains. Edited by W. Dort, Jr. and J.K. Jones, Jr. University of Kansas Press, Lawrence. pp. 355-391.

Holt, R.D., and Keitt, T.H. 2005. Species' borders: a unifying theme in ecology. Oikos, 108(1): 3-6. doi:10.1111/j.0030-1299.2005. 13145.x.

Jones, J.K., Jr. 1964. Distribution and taxonomy of mammals of Nebraska. Univ. Kans. Publ. Mus. Nat. Hist. 16: 1-356.

Jones, C.A., Choate, J.R., and Genoways, H.H. 1984. Phylogeny and paleobiogeography of short-tailed shrews (genus Blarina). In Contributions in Quaternary vertebrate paleontology: a volume in memorial to John E. Guilday. Edited by H.H. Genoways and M.R. Dawson. Carnegie Mus. Nat. Hist. Spec. Publ.. pp. 56-148.

Kaufman, D.W., and Kaufman, G.A. 1989. Nongame wildlife management in central Kansas: implications of small mammal use of fencerows, fields, and prairies. Trans. Kans. Acad. Sci. 92(3-4): 198-205. doi:10.2307/3628453.

Kays, R.W., and Wilson, D.E. 2002. Mammals of North America. Princeton University Press, Princeton, N.J.

Key, K.H.L. 1981. Species, parapatry, and the morabine grasshopper. Syst. Zool. 30(4): 425-438. doi:10.2307/2413053.

Kinkead, K.E. 2006. Iowa multiple species inventory and monitoring program technical manual. Iowa Department of Natural Resources, Des Moines.

Kirsch, E.M. 1997. Small mammal community composition in cornfields, roadside ditches, and prairies in eastern Nebraska. Nat. Areas J. 17(3): 204-211.

Klicka, J., and Zink, R.M. 1997. The importance of recent ice ages in speciation: a failed paradigm. Science (Washington, D.C.), 277(5332): 1666-1669. doi:10.1126/science.277.5332.1666.

Lee, M.R., and Zimmerman, E.G. 1969. Robertsonian polymorphism in the cotton rat, Sigmodon fulviventer. J. Mammal. 50(2): 333339. doi:10.2307/1378351. PMID:5362362.

Lister, A.M. 2004. The impact of Quaternary ice ages on mammalian evolution. Philos. Trans. R. Soc. Lond. B Biol. Sci. 359(1442): 221-241. doi:10.1098/rstb.2003.1436. PMID:15101579.

Mallet, J. 2005. Hybridization as an invasion of the genome. Trends Ecol. Evol. 20(5): 229-237. doi:10.1016/j.tree.2005.02.010. PMID:16701374.

Martin, R.E., Pine, R.H., and DeBlase, A.F. 2001. A manual of mammalogy with keys to families of the world. McGraw-Hill, New York.

Mayr, E. 1963. Animal species and evolution. Harvard University Press, Cambridge, Mass.

McNab, B.K. 1979. The influence of body size on the energetics and distribution of fossorial and burrowing mammals. Ecology, 60(5): 1010-1021. doi:10.2307/1936869.
Meylan, A. 1967. Formules chromosomiques et polymorphisme Robertsonian chez Blarina brevicauda (Say) (Mammalia: Insectivora). Can. J. Zool. 45(6): 1119-1127. doi:10.1139/z67-122. PMID:6070628.

Moncrief, N.D., Choate, J.R., and Genoways, H.H. 1982. Morphometric and geographic relationships of short-tailed shrews (genus Blarina) in Kansas, Iowa, and Missouri. Ann. Carnegie Mus. 51: 157-180.

Moore, W.S. 1977. An evaluation of narrow hybrid zones in vertebrates. Q. Rev. Biol. 52(3): 263-277. doi:10.1086/409995.

Moulton, M.P., Choate, J.R., and Bissell, S.J. 1983. Biogeographic relationships of pocket gophers in southeastern Colorado. Southwest. Nat. 28(1): 53-60. doi:10.2307/3670592.

Neal, C.M., and Lustick, S.I. 1973. Energetics and evaporative water loss in the short-tailed shrew Blarina brevicauda. Physiol. Zool. 46: $180-185$.

Oshida, T., Ohdachi, S.D., and Masuda, R. 2003. A preliminary note on banded karyotypes of the short-tailed shrew Blarina brevicauda (Mammalia, Insectivora). Caryologia, 56(4): 447-451.

Peakall, R., and Smouse, P.E. 2006. GENALEX 6: Genetic analysis in Excel. Population genetic software for teaching and research. Mol. Ecol. Notes, 6(1): 288-295. doi:10.1111/j.1471-8286.2005. 01155.x.

Phillips, C.D., Henard, C.A., and Pfau, R.S. 2007. Amplified fragment length polymorphism and mitochondrial DNA analyses reveal patterns of divergence and hybridization in the hispid cotton rat (Sigmodon hispidus). J. Mammal. 88(2): 351-359. doi:10. 1644/06-MAMM-A-089R1.1.

Reilly, S.M., Manning, R.W., Nice, C.C., and Forstner, M.R.J. 2005. Systematics of isolated populations of short-tailed shrews (Soricidae: Blarina) in Texas. J. Mammal. 86(5): 887-894. doi:10.1644/1545-1542(2005)86[887:SOIPOS]2.0.CO;2.

Schmidly, D.J., and Brown, W.A. 1979. Systematics of short-tailed shrews (genus Blarina) in Texas. Southwest. Nat. 24(1): 39-48. doi: $10.2307 / 3670623$.

Schwartz, C.W., and Schwartz, E.R. 2001. The wild mammals of Missouri. 2nd revised ed. University of Missouri Press, Columbia.

Searle, J.B. 1993. Chromosomal hybrid zones in eutherian mammals. In Hybrid zones and the evolutionary process. Edited by R.G. Harrison. Oxford University Press, New York. pp. 309-353.

Sepkoski, J.J., , Jr. 1998. Rates of speciation in the fossil record. Philos. Trans. R. Soc. Lond. B Biol. Sci. 353(1366): 315-326. doi:10.1098/rstb.1998.0212. PMID:11541734.

Shaw, D.D., Marchant, A.D., Contreras, N., Arnold, M.L., Groeters, F., and Kohlmann, B.C. 1993. Genomic and environmental determinants of a narrow hybrid zone: cause and coincidence? In Hybrid zones and the evolutionary process. Edited by R.G. Harrison. Oxford University Press, New York. pp. 165-195.

Smith, P.W. 1965. Recent adjustments in animal ranges. In The Quaternary of the United States. Edited by H.E. Wright, Jr. and D.G. Frey. Princeton University Press, Princeton, N.J. pp. 633-642.

Sullivan, R.M., Hafner, D.J., and Yates, T.L. 1986. Genetics of a contact zone between three chromosomal forms of the grasshopper mouse (genus Onychomys): a reassessment. J. Mammal. 67(4): 640-659. doi:10.2307/1381126.

Tate, C.M., Pagels, J.F., and Handley, C.O., Jr. 1980. Distribution and systematic relationship of two kinds of short-tailed shrews (Soricidae: Blarina) in south-central Virginia. Proc. Biol. Soc. Wash. 93: 50-60.

Thompson, C.W. 2008. Identification and characterization of the contact zone between two species of short-tailed shrew (Blarina) in southwestern Iowa and northwestern Missouri. M.Sc. thesis, Department of Biological Sciences, Fort Hays State University, Hays, Kans. 
Thompson, C.W., and Hoffman, J.D. 2009. Karyotype designation and habitat description of the northern short-tailed shrew (Blarina brevicauda, Say) from the type locality. Jeffersoniana, 22: 1-5.

Turelli, M., Barton, N.H., and Coyne, J.A. 2001. Theory and speciation. Trends Ecol. Evol. 16(7): 330-343. doi:10.1016/ S0169-5347(01)02177-2. PMID:11403865.

Vos, P., Hogers, R., Bleeker, M., Reijans, M., van de Lee, T., Hornes, M., Fritjers, A., Pot, J., Paleman, J., Kuiper, M., and Zabeau, M. 1995. AFLP: a new technique for DNA fingerprinting. Nucleic Acids Res. 23(21): 4407-4414. doi:10.1093/nar/23.21.4407. PMID:7501463.

Zohrer, J.J., Little, T.W., and Harr, D.C. 2006. Securing a future for fish and wildlife: a conservation strategy for Iowa. Iowa Department of Natural Resources, Des Moines.

\section{Appendix A}

The following list includes specimens of northern shorttailed shrew (Blarina brevicauda) and Elliot's short-tailed shrew (Blarina hylophaga) collected in this study. Voucher specimens are housed in the Sternberg Museum of Natural History, Fort Hays State University (MHP). Localities are arranged alphabetically by state, county, and specific locality. For specimen locality, localities are ordered by latitude from north to south and by longitude from west to east. The number of specimens collected from each locality is indicated.

\section{Blarina brevicauda}

IOWA - FREMONT COUNTY: $7 \mathrm{mi}$. W Tabor (T70N, R43W, NE 1/4 sec. 5) (40.90058 N, 95.80297 W), 4 (MHP 37676-37679); 2 mi. N, 3 1/4 mi. W Thurman (T70N, R43W, SE 1/4 sec. 20) (40.84878 N, 95.80919 W), 1 (MHP 37675). HARRISON COUNTY: 2 1/2 mi. S, 1 mi. W Woodbine (T80N, R42W, N central sec. 34) (41.70275 N, 95.72258 W), 10 (MHP 37651-37660). MILLS COUNTY: $5 \mathrm{mi}$. N, 3 3/4 mi. W Glenwood (T73N, R43W, SW 1/4 sec. 17) (41.12026 N, 95.81598 W), 3 (MHP 37680-37682); 6 3/4 mi. S, 1/4 mi. W Pacific Junction (T71N, R43W, W 1/ 2 sec. 28) (40.92325 N, 95.79880 W), 4 (MHP 3768337686); 2 1/4 mi. W Pacific Junction (T72N, R44W, SE 1/ 4 sec. 24) (41.01994 N, 95.84222 W), 1 (MHP 37687). MONTGOMERY COUNTY: 9 1/2 mi. N Red Oak (T73N, R38W, E center sec. 5) $(41.15380 \mathrm{~N}, 95.23300 \mathrm{~W}), 6$ (MHP 37691-37696); 3 1/2 mi. N Red Oak (T72N, R38W, NE 1/4 sec. 5) (41.06814 N, 95.23279 W), 3 (MHP 3768837690); 3 3/4 mi. S Red Oak (T71N, R38W, SW 1/4 sec. 9) (40.96200 N, 95.23306), 11 (MHP 37697-37707). PAGE COUNTY: 1 mi. N, 5 3/4 mi. E Essex (T70N, R38W, E center sec. 22 and $\mathrm{W}$ center sec. 23) (40.85181 N, 95.19446 W), 14 (MHP 37708-37721); 3 3/4 mi. N, 2 1/2 mi. W Yorktown (T69N, R38W, S center sec. 10) (40.78754 N, 95.20400 W), 10 (MHP 37722-37731). TAYLOR COUNTY: 3/4 mi. S, $61 / 2$ mi. E Bedford (T68N, R33W, SE $1 / 4$ sec. 26) (40.65623 N, 94.60446 W), 3 (MHP 37738-37740); 4 3/4 mi. S, 4 1/2 mi. E Bedford (T67N, R33W, SW 1/4 sec. 15) (40.59972 N, 94.64232 W), 6 (MHP 377732-37737); 1/2 mi. N, 3 1/4 mi. W Conway (T69N, R33W, SE 1/4 sec. 19) (40.76189 N, 94.68072 W), 4 (MHP 37741-37744); 3 mi. N, 2 mi. W Sharpsburg (T70N, R33W, SW 1/4 sec. 20) (40.84399 N, 94.68072 W), 2 (MHP 37745-37746).

MISSOURI - ANDREW COUNTY: 1 1/2 mi. S, $4 \mathrm{mi}$. W
Cosby (T58N, R34W, S central sec. 17) (39.84039 N, 94.74333 W), 3 (MHP 37747-37749). BUCHANAN COUNTY: 2 $3 / 4$ mi. W Easton (T57N, R34W, SE 1/4 sec. 27) (39.72134 N, 94.69326 W), 1 (MHP 37750). CALDWELL COUNTY: 2 3/4 mi. S, 1 3/4 mi. W Kidder (T57N, R29W,

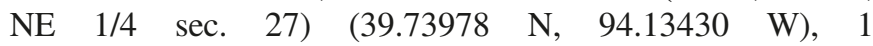
(MHP 37751); 1 1/2 mi. N, 8 mi. W Kingston (T56N, R29W, S central sec. 27) (39.66590 N, 94.17817 W), 1 (MHP 37752). DAVIESS COUNTY: 3 1/2 mi. S, $1 / 4 \mathrm{mi}$. W Altamont (T58N, R28W, W $1 / 2$ sec. 18) (39.84066 N, 94.09297 W), 1 (MHP 37753); 1 1/2 mi. S, 3/4 mi. E Pattonsburg (T60N, R29W, SW $1 / 4$ sec. 11) $(40.0424 \mathrm{~N}$ 94.12634 W), 3 (MHP 37754-37756); 5 1/2 mi. S, 2 1/4 mi. W Winston (T59N, R29W, SE 1/8 sec. 31), 1 (MHP 37757). HARRISON COUNTY: 3 mi. S, 2 1/4 mi. W Bethany (T63N, R28W, S center sec. 29) (40.22489 N, 94.07505 W), 1 (MHP 37758); 4 1/4 mi. S, 1 1/4 mi. W Brooklyn (T64N, R28W，NW 1/8 sec. 21) (40.33784 N, 94.06418 W), 2 (MHP 37759-37760); 4 mi. S, 1 1/4 mi. W Brooklyn (T64N, R28W, SW 1/8 sec. 16) (40.33958 N, 94.06421 W), 2 (MHP 37761-37762); $13 / 4$ mi. N, 2 1/4 mi. E Washington Center (T65N, R29W, NE 1/4 sec. 11) (40.44926 N, 94.11995 W), 1 (MHP 37764); 1 1/4 mi. N, 2 1/4 mi. E Washington Center (T65N, R29W, SW 1/4 sec. 12) (40.44375 N, 94.11970 W), 1 (MHP 37763). NODAWAY COUNTY: 2 mi. S Clyde (T63N, R34W, SE 1/4 sec. 25) (40.23114 N, 94.66916 W), 3 (MHP 37765-37767); 5 1/2 mi. E Guilford (T62N, R33W, NW 1/4 sec. 21) (40.16885 N, 94.63558 W), 2 (MHP 37768-37769). PLATTE COUNTY: 3 1/2 mi. S, 1 1/2 mi. W Ridgely (T53N, R34W, SE $1 / 4$ sec. 13) (39.40308 N, 94.66180 W), 2 (MHP 3777037771). RAY COUNTY: 1 1/4 mi. S, 3 mi. E Lawson (T52N, R29W，NE 1/4 sec. 9) (39.42221 N, 94.15393 W), 1 (MHP 37772); WORTH COUNTY: $1 \mathrm{mi}$. N, 1/4 mi. W Sheridan (T66N, R33W, SE 1/4 sec. 10) (40.53464 N, 94.61795 W), 1 (MHP 37776); 2 3/4 mi. S, $1 / 4$ mi. W Sheridan (T66N, R33W，SE 1/4 sec. 34) (40.48234 N, 94.61762 W), 3 (MHP 37773-37775).

\section{Blarina hylophaga}

IOWA - FREMONT COUNTY: 1/2 mi. S, 4 1/4 mi. W Hamburg (T67N, R42W, NE $1 / 4$ sec. 26) $(40.60007 \mathrm{~N}$, 95.73559 W), 2 (MHP 37777-37778); 2 1/2 mi. S, 8 1/2 mi. W Sidney (T68N, R43W, NE 1/4 sec. 18) (40.71336 N, 95.80990 W), 4 (MHP 37779-37782); 1/4 mi. S, 3 mi. W Thurman (T70N, R43W, SE 1/4 sec. 32) (40.81604 N, $95.80370 \mathrm{~W}$ ), 1 (MHP 37792); 3 1/4 mi. S, $31 / 2 \mathrm{mi}$. W Thurman (T69N, R43W, center sec. 5) (40.80596 N, 95.81305 W), 5 (MHP 37783-37787); 1 1/4 mi. S, 3 1/2 mi. W Thurman (T69N, R43W, S center sec. 8) (40.79212 N, 95.81293 W), 4 (MHP 37788-37791). PAGE COUNTY: 1 1/4 mi. N Blanchard (T67N, R38W, NW 1/8 sec. 28) (40.59473 N, 95.22154 W), 1 (MHP 37793); 4 1/4 mi. N Coin (T68N, R38W, S central sec. 8) (40.71316 N, 95.22879 W), 3 (MHP 37811-37813); 3 1/4 mi. N, 1/2 mi. W Coin (T65N, R39W, E center sec. 11) (40.70242 N, 95.23856 W), 4 (MHP 37807-37810); 1 mi. N, 1/4 mi. E Coin (T68N, R38W, S center sec. 29) (40.67113 N, 95.23052 W), 13 (MHP 37794-37806); 1 mi. N, 3 mi. W Yorktown (T69N, R38W, SE 1/4 sec. 28) (40.74735 N, 95.21349 W), 6 (MHP 37814-37819). 
KANSAS - ELLIS COUNTY: 9 1/4 mi. N, $31 / 4 \mathrm{mi}$. W Hays (T12S, R19W, W center sec. 13) (39.01089 N, 99.39023 W), 7 (MHP 37661-37667); 9 1/4 mi. N, $31 / 4$ mi. W Hays (T12S, R19W, E center sec. 14) (39.01055 N, 99.39038 W), 7 (MHP 37668-37674).

MISSOURI - ATCHISON COUNTY: 6 1/2 mi. E Fairfax (T64N, R39W, SE 1/4 sec. 22) (40.33896 N, 95.27452 W), 9 (MHP 37820-37828); 1 1/2 mi. N, 7 1/2 mi. E Tarkio (T65N, R39W, E center sec. 11) (40.45782 N, $95.25373 \mathrm{~W})$, 8 (MHP 37829-37836). HOLT COUNTY: 8 1/4 mi. N, 2 1/4 mi. W Mound City (T63N, R39W, SW 1/4 sec. 23) (40.25369 N, 95.27577 W), 6 (MHP 37839-37844); 1 1/4 mi. N, 5 mi. E Mound City (T62N, R38W, SW 1/4 sec. 25) (40.14923 N, 95.14478 W), 2 (MHP 37837-37838). NODAWAY COUNTY: 3
1/4 mi. N, 8 1/2 mi. E Maryville (T65N, R34W, SE 1/ 4 sec. 33) (40.38793 N, 94.72201 W), 2 (MHP 3784537846); 1 1/2 mi. N, 3 3/4 mi. W Parnell (T65N, R34W, $\begin{array}{lllllll}\text { NW } & 1 / 4 & \text { sec. } & 10) & (40.46595 & \text { N, } 94.72080 & \text { W), } 1\end{array}$ (MHP 37849); 2 mi. S, 5 1/4 mi. W Parnell (T65N, R34W, NE 1/4 sec. 28) (40.40071 N, 94.72203 W), 2 (MHP 3784737848); 2 1/2 mi. W Ravenwood (T64N, R34W, E center sec. 16) (40.35215 N, 94.72237 W), 3 (MHP 37850-37852).

\section{Blarina brevicauda $\times$ Blarina hylophaga (hybrid)}

IOWA - PAGE COUNTY: 3 3/4 mi. N, 2 1/2 mi. W Yorktown (T69N, R38W, S center sec. 10) (40.78754 N, 95.20400 W), 1 (MHP 37853). 